\title{
The Effect of STEM Education Approach in Science Teaching: Photosynthesis Experiment Example
}

\author{
Faruk ÖZTÜRK *1 (1) Durmuş ÖZDEMIR 2 (1) \\ ${ }^{1}$ Kütahya Dumlupinar University, Institute of Science Studies, Kütahya, Turkey, faruk.ozturk@ogr.dpu.edu.tr \\ ${ }^{2}$ Kütahya Dumlupinar University, Faculty of Engineering, Kütahya, Turkey durmus.ozdemir@dpu.edu.tr \\ ${ }^{*}$ Corresponding Author: faruk.ozturk@ogr.dpu.edu.tr
}

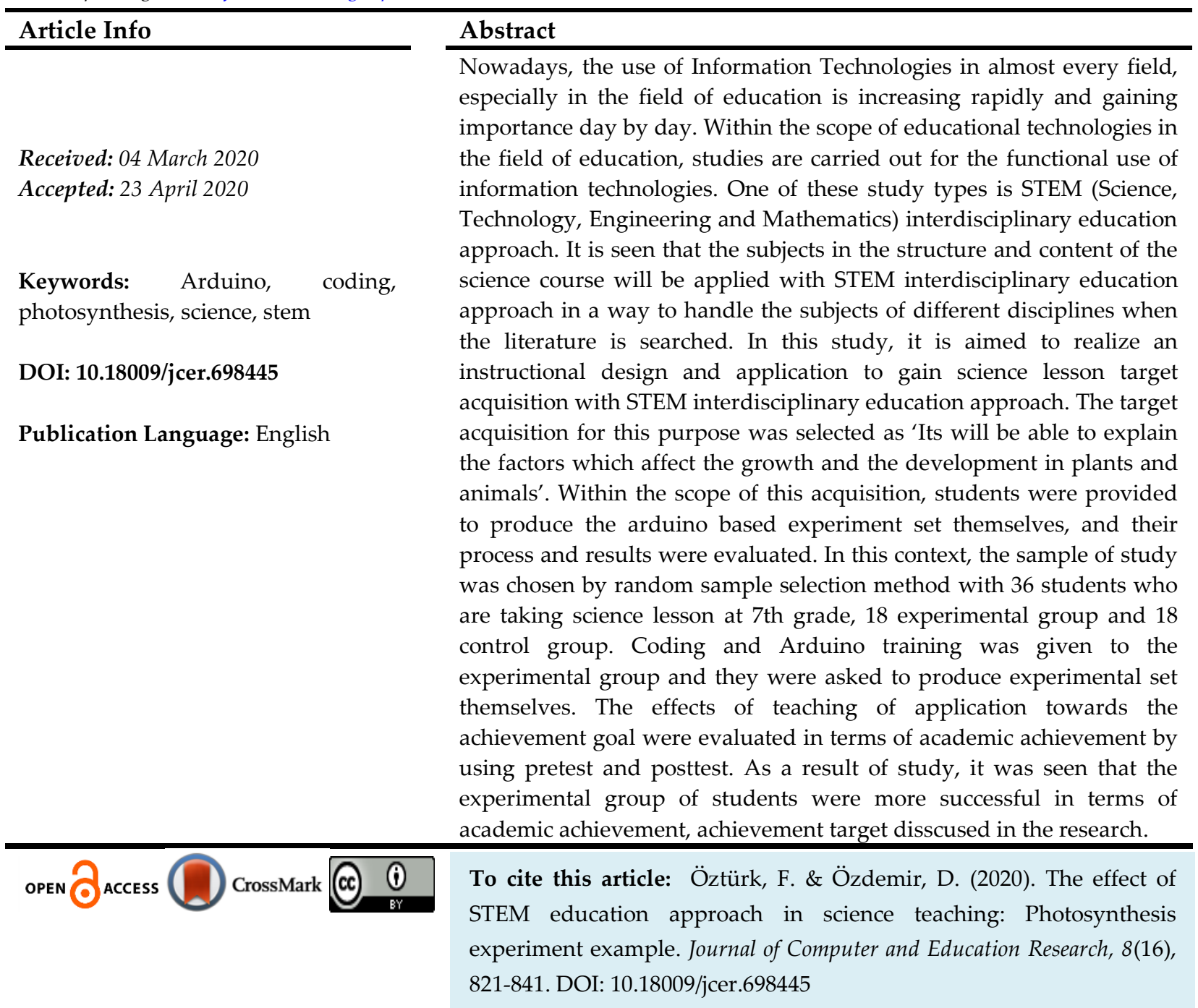

\section{Introduction}

The changing of the needs of society every day is one of the important factors that direct science. For example, although many of the concepts and developments related to information technologies have emerged to be used for different purposes today. It is known that it is used in many fields, especially in education, and it is known that it has advantages over traditional education (Akçetin, 2017; Sarıŏlu \& Girgin, 2020). Advances in technology 
have been continuously used as a structure that supports teaching as educational materials and instructional technologies (Gök, 2020). In today's educational policy, which aims to raise individuals who are competent in the skills of the 21st century, in addition to technology, coding skills are also considered a skill (Sayın \& Seferoğlu, 2016). Instead of thinking of coding as a discipline alone, it would be better to consider it as an interdisciplinary approach where students can gain 21st century skills and produce solutions to future problems (Demirer \& Sak, 2016). The need for individuals producing, thinking, questioning with what they learn, especially positive sciences such as mathematics and science, is increasing day by day. STEM interdisciplinary education approach is the most recent development that can provide this need (Samsudin, Jamali, Zain, \& Ale Ebrahim, 2020).

STEM is an interdisciplinary approach that is formed by combining the initials of the words Science, Technology, Engineering and Mathematics providing permanent learning by aiming to reduce the knowledge to daily life (Yildirım \& Altun, 2015). Since engineering education has not been reduced to primary and secondary school levels, STEM related gains are not included in education programs in different disciplines (Samsudin et al., 2020).

Countries that are aware of the fact that knowledge is a power have prioritized updating the education policies within the scope of STEM in order to make the information functional (Aydeniz et al., 2015). In the STEM application report prepared by the Ministry of National Education, the Netherlands, Norway, France, Malta, Croatia, Lithuania, England, Scotland, Ireland, Israel, Bulgaria, Switzerland, Czech Republic, Estonia, Greece, Spain, especially the USA, Russia and China countries such as Finland, Romania, Latvia, Poland and Italy attach importance to supporting and increasing the studies on STEM application (Ministry of Education [MoNE], 2015).

In our country, although there is no direct action plan for STEM education approach, the objectives and targets for strengthening STEM studies are specified in the 2015-2019 Ministry of Education Strategic Plan (MoNE, 2015). In addition, the Applied Sciences (Science and Engineering) unit was added with the amendment made in the science program in 2017, and students were provided to exhibit their products during the projects and science festivities they held during the year (MoNE, 2018). This unit enables the development of samples for STEM application. According to the STEM Education Report, it is seen that it is possible to apply the studies carried out in the Technology and Design course in the 7th and 8th grades towards STEM (MoNE, 2015). In addition, the business world in our country 
supports the STEM interdisciplinary education approach. TUSIAD 's by 2023, according to the report Towards Turkey in STEM requirements need to be more active in investing in STEM interdisciplinary education approach and the necessity of disposing of the necessary steps to be able to play a stronger role in global competition are highlighted (Turkish Industry and Business Association [TIBA], 2015).

One of the important studies that will combine interdisciplinary work with science, mathematics and engineering is coding based robotic applications. In addition to the technological elements that have entered the learning environments, the worldwide interest in the use of robots integrated with educational programs has increased (Özdemir \& Karaman, 2017). He is involved in studies that show that students participating in Robotic Application and 3D design development activities have positive effects on problem solving and creative thinking skills (Akyüz, Bilgici \& Y1ld1z, 2018). Due to the structure of the science course, its similarity to the stages in the process of creating robots, their integration with them is quite similar and modular. Because more precise and practical measurements can be obtained by making sensitive measurements with sensors designed for various robotic sets, or subjects in the units that contain the physics subjects of the science course with mechanical parts can be comfortably animated (Koç \& Böyük, 2013).

When the literature is examined, it is seen that studies are carried out using different robotic materials. Especially LEGO and arduino products come to the fore in these studies. Some of these studies are discussed below.

Qidwai, Riley and El-Sayed (2013) emphasized that, the importance of robot competitions for high school students to arouse and motivate against computer science in their study. In this context, the competition was tried to be held using The LEGO Mindstorms Educational kit, and the task lists to be performed by the robots were given and the participants were asked to perform.

In the study conducted by Kuo, Tseng and Yang (2019), STEM interdisciplinary education approach was applied in order to increase the motivation of university students. For this purpose, his lectures were given in the fields of industrial design, imagination development and guidance and consultancy. As a result of the study, they stated that STEM interdisciplinary education approach gained the ability to handle problems in an integrative and inclusive way, and is interesting and inspiring. 
Bobtsov et al. (2011) took a bachelor's level education and conducted a study on adaptive control theory using LEGO Mindstorms NXT technology. They stated that as a result of the study, they were able to attract students' interest in the subject and come up with new algorithms.

Docekal and Golimbievsky (2018) have designed various experimental environments using arduino and circuit elements for a low-cost laboratory design. They suggested that these environments are very suitable for teaching cybernetics and control systems, and students can be improved in their knowledge and skills.

Karahoca and Uzunboylu (2011) designed a project-based learning environment in order to support the subject of electricity within the scope of the science course by addressing elementary school students aged 10-15. As a result of the curriculum, which was carried out by informing the students about robots, it was concluded that those who are enthusiastic from the students realized more successful projects and the opinion that robots had a great impact on students' academic development.

In the study carried out by Koç and Böyük (2013), they stated that it is possible to adapt more precise measurements in experiments using the Lego Mindstorms NXT Training set and to adapt it to experiments that will be applied especially in the subjects of science such as force and motion, light and sound, electricity in our life, matter and heat.

When the literature is examined, it has been seen that the structure and content of the science course to cover the subjects of different disciplines can be applied with the STEM interdisciplinary education approach. In addition, the fact that science course offers students the opportunity to research and question increases the applicability of the STEM interdisciplinary education approach. Saraçoğlu and Kahyaoğlu (2018) stated that there is a significant relationship between students' scientific research skills and their attitude towards curiosity, motivation and science lesson. In this study, with the STEM interdisciplinary education approach, it was aimed to realize an instructional design and implementation for the goal acquisition of science course. For this purpose the targeted topic "explains factors affecting growth and development in plants and animals" was selected and the concept of photosynthesis was discussed. In line with this acquisition, students participated in an arduino-based activity, and the process and results were evaluated. 


\section{Method}

In this study, with the STEM interdisciplinary education approach, it was aimed to realize an instructional design and application for the goal acquisition of science course. The target acquisition subject determined for this purpose has been selected as "explains the factors affecting growth and development in plants and animals.". The concept of photosynthesis in plants for this acquisition is discussed. In order to achieve this achievement, students were provided to produce the arduino based experiment set themselves, and the process and results were evaluated within the scope of the following research questions.

Arduino based experimental design designed for the target acquisition of "Science explains the main factors affecting growth and development in plants and animals", which is suitable for STEM interdisciplinary education approach;

1- The effect of students on their academic success,

2- Its effect on participation processes has been investigated.

\section{Research Model}

In this study, a semi-experimental pattern model with control group based on pretestposttest measurements was selected to measure the effect of STEM interdisciplinary education approach on the teaching of science course. In accordance with this model, two groups have been created with the random method. Course activities were carried out by a specialist teacher. The gains for the control group have been conveyed with a traditional approach. For the experimental group, STEM interdisciplinary education approach was used. Both groups were tested before and after the experiment, and their effect on the dependent variable was tried to be measured. For this purpose, the unit explains the "Factors affecting growth and development in plants and animals.".

\section{Study Group}

The sample of the study was determined by Purposeful Sampling, which is one of the Non-Selective Sampling Methods (Büyüköztürk, Kılıç Çakmak, Akgün, Karadeniz \& Demirel, 2011). Purposeful sampling is based on the method of selecting information-rich groups in cases where the research should represent a wide range of environments and be able to conduct in-depth research (Büyüköztürk, et al., 2011). Research was carried out in 2018/2019 academic year and work within the scope of a junior high school in Turkey 7th 
grade students were selected. While determining the study group, it was taken into consideration that the students received Arduino Coding training and had basic computer skills within the scope of the Information Technologies and Software course when they were at the 6th grade level. Classroom is divided into two groups, each with 18 people as control and experiment. These conditions are to organize the study group, with a total of 36 students, 17 girls and 21 boys.

\section{Data Collection Tools}

The academic success of the students participating in the research was measured with the pre-test and post-test control group model. A test exam consisting of 10 questions was prepared by the researchers by taking the content used in the pre-test and post-test studies, the opinions of the $\mathrm{PhD}$ specialist in the field of science and the opinions of 2 science teachers. In addition to benefiting from the works of Tekkaya and Balc1 (2012), the questions of the academic achievement test were selected from the questions prepared by the Ministry of Education, Directorate of Assessment, Evaluation and Examination Services. The questions used in these studies are considered to be reliable. Again, the validity of the academic achievement test has been provided by using the relevant expert opinion and related literature.

During the study, students' interest in arduino and coding and their difficulties were observed by the researchers who conducted the study using the rough evaluation form. In addition, the students' opinions about the study were taken with the student interview form. For the validation of the rough evaluation form and the student interview form, these forms were checked by the experts and the questions included the desired thought and the appropriate language was used. In order to ensure the reliability of the rough evaluation form and the student interview form, it was ensured that the research was appropriate with the purpose and research questions. Observations and interviews are recorded while using data collection tools and risks of disappearance are minimized.

\section{Data Analysis}

Quantitative data collected during the study were analyzed with the help of SPSS program. The study consists of two groups with experimental and control groups. Dependent sample t-test was used to compare the averages of the data obtained by applying pre-test and post-test to these groups and measure whether there is a significant distribution. 
In addition, the data obtained from the rough evaluation forms were presented by applying the content analysis method.

\section{Materials Used and Design Process}

In the study, light intensity and soil humidity variables were selected for students to comment on the change in the environment, and air quality sensor was used to measure the $\mathrm{CO}_{2}$ amount in the environment for their comments on the amount of photosynthesis. Arduino microcontroller was used for the control of these sensors in order to be easily programmable. The design process of the materials and application used below is presented in related headings.

\section{Arduino Uno}

Arduino UNO was used as a microcontroller in the sample experiment design. Arduino Uno has 14 digital input / output pins. 6 of them can be used as PWM output. It also has 6 analog inputs, one $16 \mathrm{MHz}$ crystal oscillator, USB connection, power jack, ICSP header and reset button. By connecting Arduino Uno to a computer, you can operate it with an adapter or battery. The picture below shows an example Arduino Uno R3.

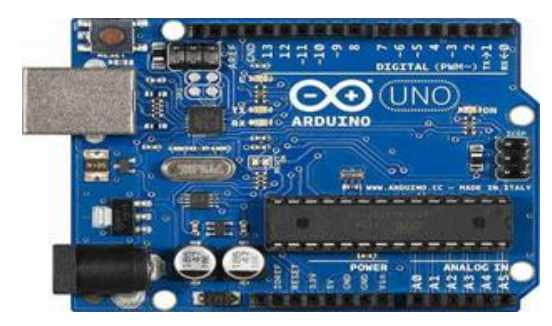

Figure 1. Arduino UNO

In the study, USB port was used to load the software to the arduino circuit. USB port is used again to power Arduino UNO. In order to measure sensor values, soil moisture sensor, LDR light sensor and MQ-135 air quality sensor were connected to analog inputs and the values were obtained by transferring them to the computer via serial port.

\section{Soil Moisture Sensor}

There are probes that measure the amount of moisture in the soil on which it is immersed. As the moisture content increases or decreases, the moisture content in the soil can be interpreted by producing different resistance. It is installed in the pot to measure the moisture level in the soil of the plant in the experiment. It is provided to read the values measured by connecting A1 analog pin on Arduino UNO (Kızıl, Aksu \& Çamoğlu, 2018). 
While the value of the sensor, which can take values between 0 and 1023, was read as close to 1000 in the first measurements, it was observed that the students approached 0 by adding water to the soil to change the environmental conditions.

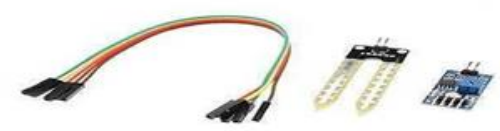

Figure 2. Soil moisture sensor

\section{LDR Light Intensity Sensor}

It is the sensor that produces resistance according to the intensity of the light in the environment. Increasing resistance in the dark environment decreases as the light intensity increases and allows us to interpret the light intensity. It was added to the experimental environment to measure the need of light for the plant in the experiment to perform photosynthesis. It is provided to read the measured values by connecting the analog pin A0 on Arduino UNO. Since the value of the sensor, which can take a value between 0 and 1023, was evaluated as the value of the experimental light level was low in the first measurements, it was observed that the sensor value approached 300 by changing the ambient conditions of the students and increasing the light level in the environment to increase photosynthesis (Xi et al., 2017).

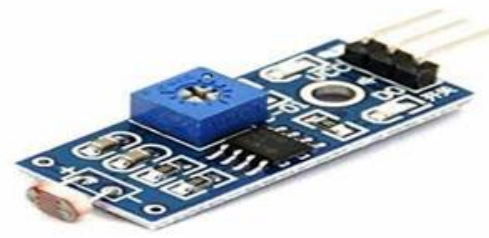

Figure 3. LDR light intensity sensor

\section{MQ-135 Air Quality Measurement Sensor}

This analog output sensor allows us to measure and interpret various gases in the air. Air quality changes as the plant in the experiment performs photosynthesis. Thanks to this sensor, the effect of photosynthesis was measured by changing the ambient conditions. It is provided to read the values measured by connecting A2 analog pin on Arduino UNO. The sensor takes the value 1 if the oxygen amount is high, and 0 if the oxygen amount is low. In the first measurements made by the students, the sensor gave the value 0 , then it was 
observed that the students gave a value of 1 by intervening in the experimental environment (Priyanka, Sangeetha, Suvedha \& Vijayalakshmi, 2017).

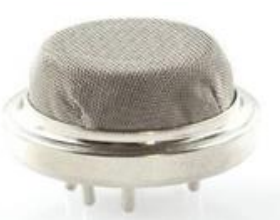

Figure 4. MQ-135 Air quality measurement sensor

\section{Arduino mBlock Editor}

There are many editors for Arduino programming. In this study, mBlock program was used considering the students' class level, and the necessary arrangements were made on the Arduino editor. mBlock is a block-based programming software designed for programming by children, developed according to Scratch 3.0 and Arduino codes. In this study, v3.4.11 version of mBlock was used.

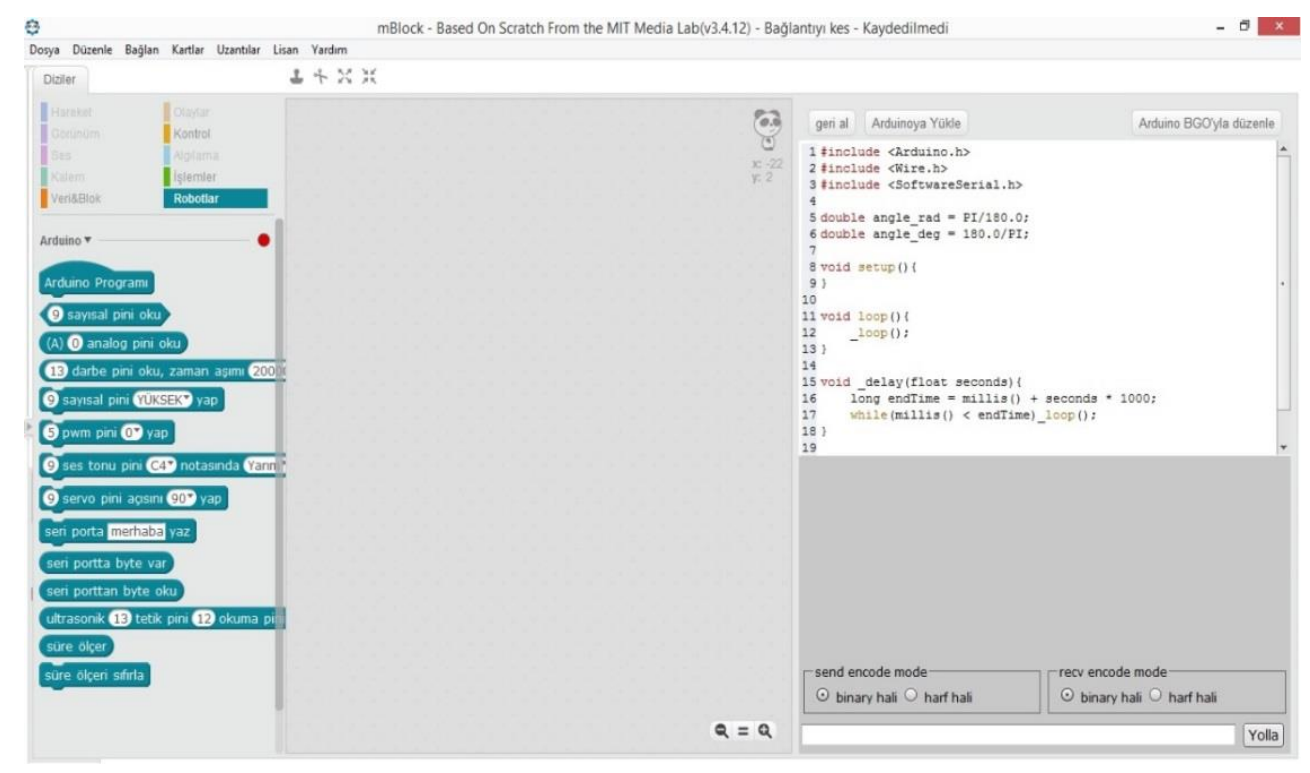

Figure 5. mBlock editor

\section{Sample Experimental Design with Arduino}

Using the Arduino circuit elements, the circuit is designed in accordance with the following scheme. In our experiment, a working environment was created by considering the three factors that affect photosynthesis made by plants, moisture in the soil, sunlight intensity and $\mathrm{CO} 2$ emission. The solar light intensity, soil moisture and carbon dioxide measurement sensors used are connected to the A0, A1 and A2 analog pins of Arduino UNO, respectively, and the measurement values are taken. The resistance values measured 
to the mBlock program are displayed on the USB port and students are provided to prepare reports with their observations. Then, by interfering with sunlight, soil moisture from outside, the sensors are observed by changing the resistance values of the sensors and the final state of the photosynthesis plant to create a report again and to compare the differences between the two reports they have created and interpret the factors affecting the photosynthesis. The circuit diagram, connection states and general operation of the experimental setup created in Figure 6 are presented in a diagram.

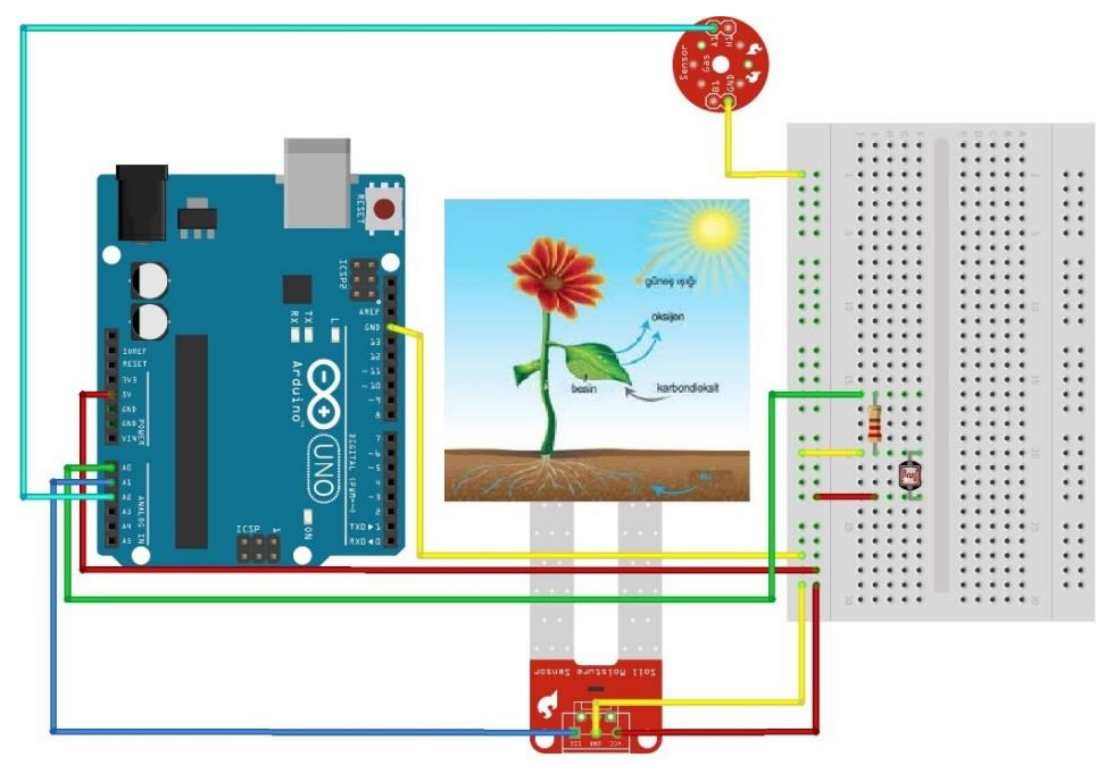

Figure 6. Arduino circuit diagram

\section{Instructional Content and Design}

The objective acquisition in the 7 th grade science class curriculum of primary education explains the basic factors affecting growth and development in plants and animals. Target achievements are as shown in Table 1 (MoNE, 2018).

Table 1. Achievements to be achieved

\section{Primary Education 7th Grade Science Course Target Achievement}

Explains the main factors affecting growth and development in plants and animals.

\section{Sub-Achievements to be Reached}

Learns the basic nutrients required for a living thing to live.

Associates the technological applications with the Science course. 
In our research, the target gains with the experimental set designed as a result of the interviews with the field experts and the literature study examined are presented as in Figure 7 (Efe, Oral, Efe \& Sünkür, 2011).

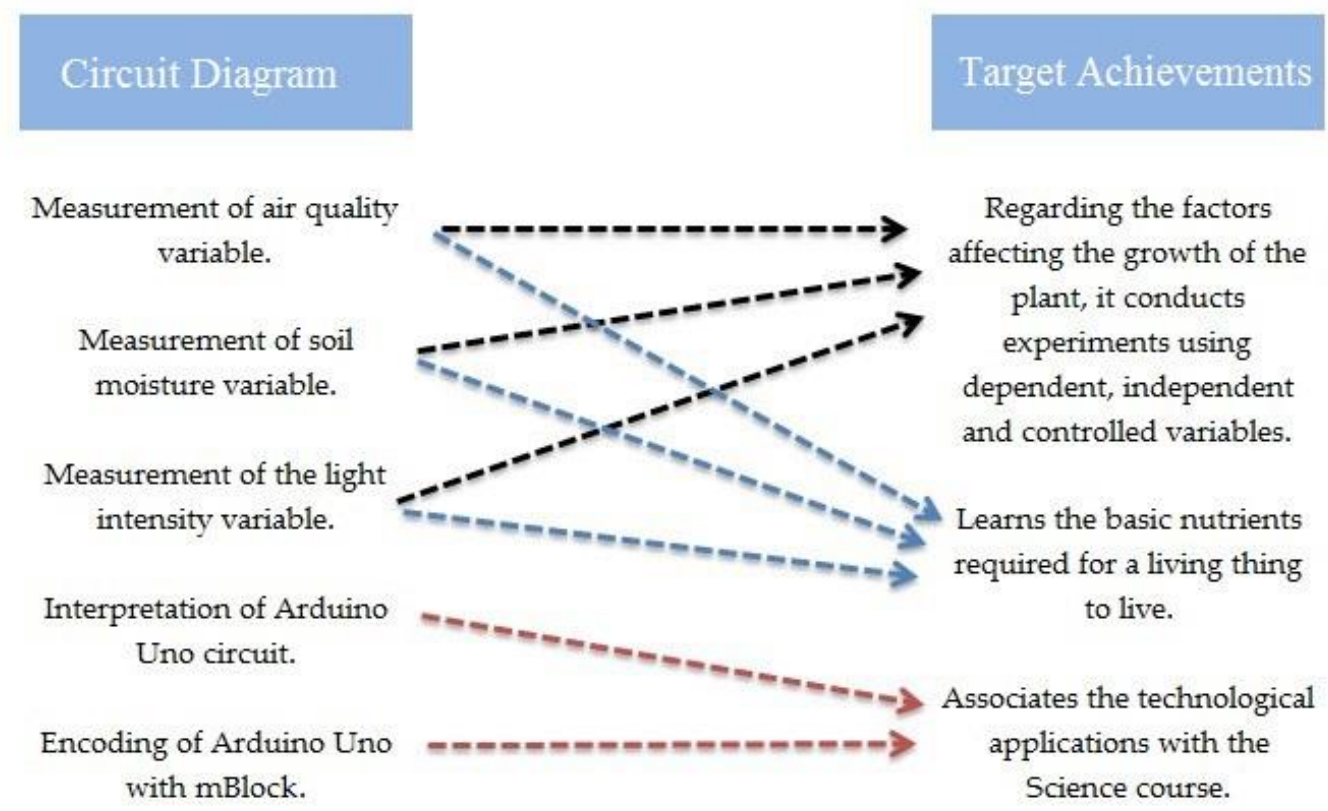

Figure 7. Matching the designed experiment and curriculum achievements

\section{Course and Process}

At this stage of the study, it was carried out in 4 stages as measuring the pretest and pre-knowledge levels of the students, performing the course content with the experimental set suitable for STEM interdisciplinary education approach, simultaneously applying the control group with the traditional method and then carrying out evaluation with post-test.

The content used in the course processing and pre-test post-test studies was carried out by the researchers by taking the opinions of the $\mathrm{PhD}$ specialist in the field of science and the opinions of 2 science teachers. The training plan was planned as 3 class hours and all the stages were recorded with photographs. The course application is schematized in Figure 8. 


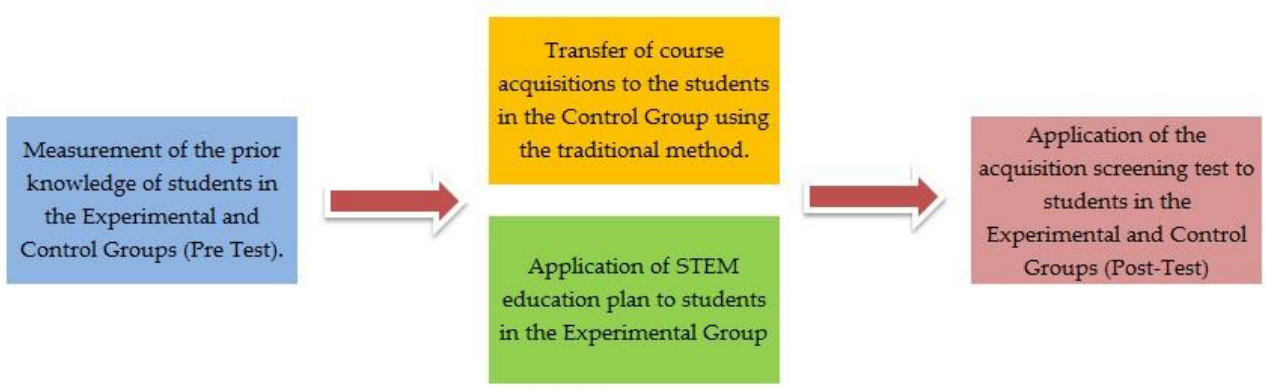

Figure 8. The way to be followed while implementing the training plan

A pre-test consisting of 10 multiple-choice questions related to the acquisition of the students explains the main factors affecting growth and development in plants and animals. The results obtained as a result of the pretest are as indicated in Table 2 .

Table 2. Control group and experimental group pretest results

\begin{tabular}{|c|c|c|c|}
\hline \multicolumn{2}{|c|}{ Control Group } & \multicolumn{2}{|c|}{ Experimental Group } \\
\hline Student Name & Pre Test & Student Name & Pre Test \\
\hline Student -1 & 6 & Student -1 & 2 \\
\hline Student -2 & 2 & Student -2 & 3 \\
\hline Student -3 & 2 & Student -3 & 4 \\
\hline Student -4 & 6 & Student -4 & 5 \\
\hline Student -5 & 3 & Student -5 & 6 \\
\hline Student -6 & 5 & Student -6 & 4 \\
\hline Student -7 & 5 & Student -7 & 6 \\
\hline Student -8 & 4 & Student -8 & 3 \\
\hline Student -9 & 3 & Student -9 & 6 \\
\hline Student -10 & 6 & Student -10 & 2 \\
\hline Student -11 & 3 & Student -11 & 5 \\
\hline Student -12 & 3 & Student -12 & 6 \\
\hline Student -13 & 4 & Student -13 & 5 \\
\hline Student -14 & 3 & Student -14 & 4 \\
\hline Student -15 & 4 & Student -15 & 6 \\
\hline Student -16 & 3 & Student -16 & 2 \\
\hline Student -17 & 5 & Student -17 & 3 \\
\hline Student -18 & 5 & Student -18 & 6 \\
\hline Average & 4 & Average & 4,33 \\
\hline
\end{tabular}

When the pretest results are examined, it is seen that the students in the control group can answer a maximum of 6 questions and the average is 4 . When the pretest results of the students in the experimental group are analyzed, it is seen that the students with the most correct answers can answer 6 correct questions, but their average is 4.33 since they have more correct answers than the control group.

The control group accomplished the students with a science teacher within the scope of 1 lesson hour. During this lesson, the students were asked the questions "What are the factors that are necessary for the growth and development of the plant?", "What are the 
environmental conditions affecting the rate of photosynthesis?", "What is the change in the $\mathrm{CO}_{2}$ rate that the plant secretes during photosynthesis?" their opinions were tried to be answered. Simultaneously, the application lesson activity carried out with the above mentioned gains experimental set was carried out to the experimental group and it was tried to find the questions directed to the control group with the application.

During the course hours, Experimental Group students who will use an appropriate control set suitable for STEM interdisciplinary education approach are included in the information technologies class and they are divided into 4 subgroups so that they can make collaborative learning. As the dependent variable, the light intensity, soil moisture value and the amount of carbon dioxide were determined and the Arduino circuit diagram specified in Figure 6 was introduced to the students.

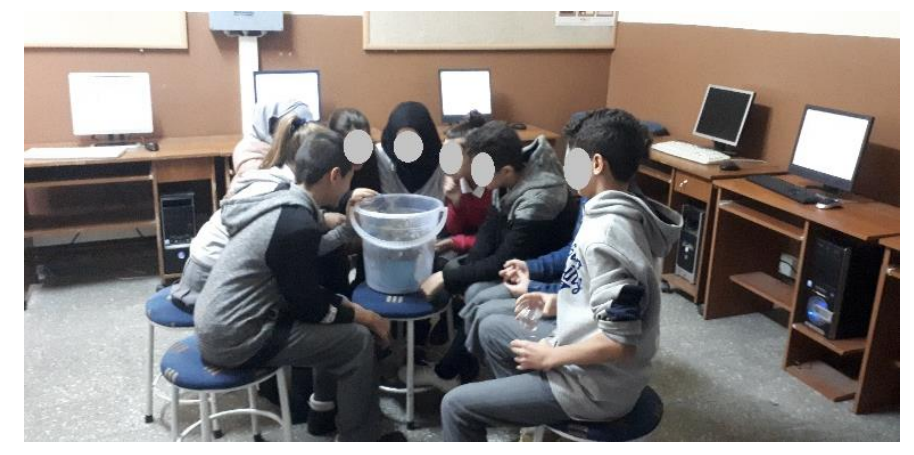

Figure 9. Introducing the experimental setup

After introducing the circuit diagram, each student group was taken to computer and they were provided to encode the experimental setup designed in mBlock code editor under the supervision of Information Technology and Software teacher. It was observed that almost all of the students were motivated during the study promotion phase.

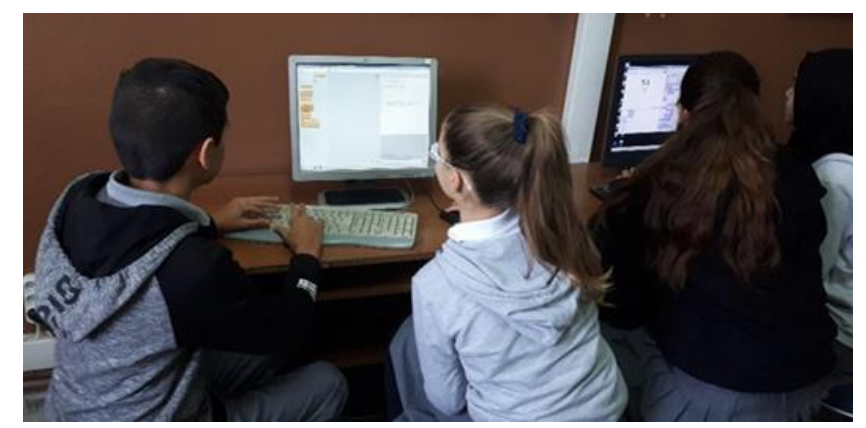

Figure 10. Performing coding processes

After the coding process the students made measurements of the light intensity, soil moisture value and the amount of carbon dioxide produced in the experimental 
environment, and they were provided to note the four different measurement values they determined. According to the first measurements, soil moisture value was between 950 and 1000, light intensity value was between 0 and 50 and air quality value was 0 for all student measurements and these measurements were noted for later evaluation by students.

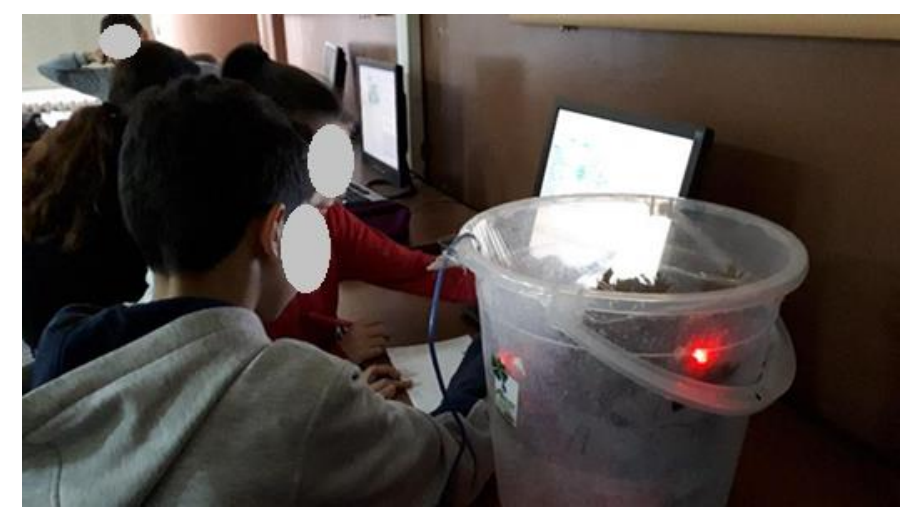

Figure 11. Students note the first measurement values

After the first measurements, the students watered the soil of the plant and brought the plant to a spot that receives sunlight. In this way, students were provided to interfere with the variables that affect photosynthesis. After the students observed the plant for a while, soil moisture, light intensity and air quality values were measured again. As a result of the students' intervention to the experimental environment, soil moisture was measured between 100 and 150, light intensity was between 400 and 650 and air quality was measured as 1.

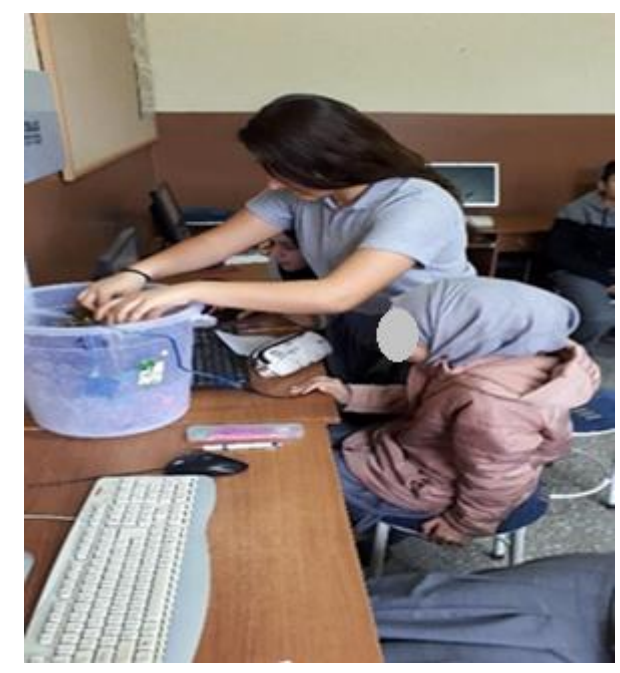

Figure 12. Students interfere with the variables in the experiment 


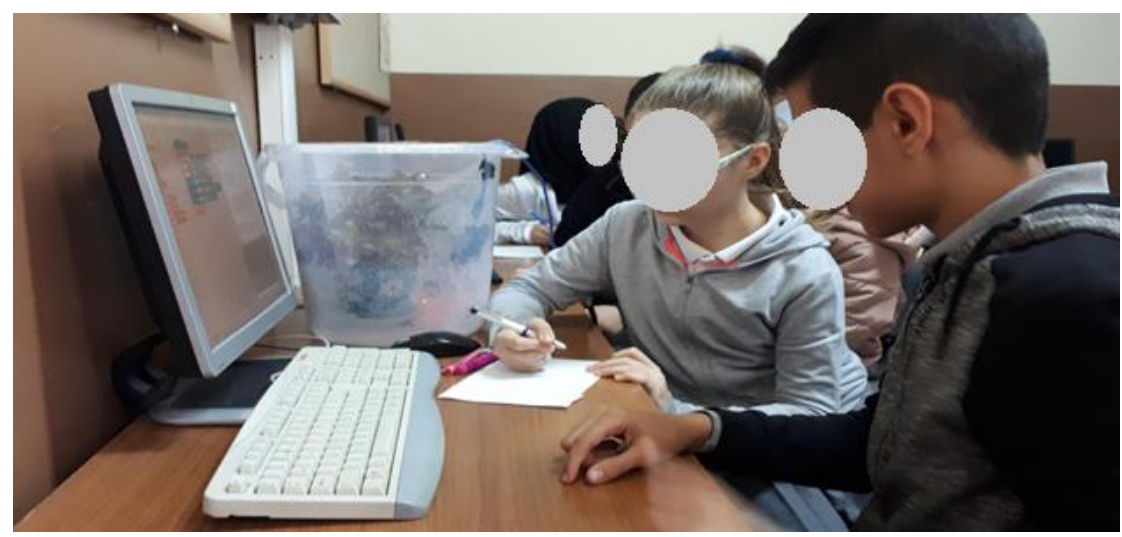

Figure 13. Students note the last measurement values

After the study was completed, students' opinions about the first measurement and the second measurement values were taken and a discussion was made on the subject. At the last stage, the post-test was applied to the experimental and control group students and the results are shown in Table 3.

Table 3. Control group and experimental group post-test results

\begin{tabular}{cccccccc}
\hline & Control Group & \multicolumn{5}{c}{ Experimental Group } \\
\hline Student & Pre-Test & Post-Test & Success & Student & Pre-Test & Post-Test & Success \\
\hline Student-1 & 6 & 9 & 3 & Student-1 & 2 & 9 & 7 \\
\hline Student-2 & 2 & 4 & 2 & Student-2 & 3 & 8 & 5 \\
\hline Student-3 & 2 & 7 & 5 & Student-3 & 4 & 7 & 3 \\
\hline Student-4 & 6 & 8 & 2 & Ögrenci-4 & 5 & 10 & 5 \\
\hline Student-5 & 3 & 9 & 6 & Öğrenci-5 & 6 & 10 & 4 \\
\hline Student-6 & 5 & 8 & 3 & Student-6 & 4 & 8 & 4 \\
\hline Student-7 & 5 & 5 & 0 & Student-7 & 6 & 7 & 1 \\
\hline Student-8 & 4 & 5 & 1 & Student-8 & 3 & 9 & 6 \\
\hline Student-9 & 3 & 6 & 3 & Student-9 & 6 & 10 & 4 \\
\hline Student-10 & 6 & 7 & 1 & Student-10 & 2 & 8 & 5 \\
\hline Student-11 & 3 & 6 & 3 & Student-11 & 5 & 9 & 4 \\
\hline Student-12 & 3 & 6 & 3 & Student-12 & 6 & 10 & 4 \\
\hline Student-13 & 4 & 7 & 3 & Student-13 & 5 & 8 & 3 \\
\hline Student-14 & 3 & 8 & 5 & Student-14 & 4 & 8 & 4 \\
\hline Student-15 & 4 & 7 & 3 & Student-15 & 6 & 9 & 3 \\
\hline Student-16 & 3 & 7 & 4 & Student-16 & 2 & 9 & 7 \\
\hline Student-17 & 5 & 6 & 1 & Student-17 & 3 & 7 & 4 \\
\hline Student-18 & 5 & 7 & 2 & Student-18 & 6 & 9 & 3 \\
\hline AVERAGE & 4 & 6,77 & 2,77 & AVERAGE & 4,33 & 8,66 & 4,33 \\
\hline & & & & & & & \\
\hline
\end{tabular}

When the post-test results in Table 3 are analyzed, it is seen that there is more increase in the number of correct questions of the students in the experimental group. The academic 
success average of the control group increased by 2.77 points to 6.77 . However, the average academic achievement of students in the experimental group increased by 4.33 points to 8.66 . Although there are students in the control group who do not increase the correct number, there is an increase in the number of correct questions in all students in the experimental group.

\section{Findings}

\section{Academic Success Test Findings (Pretest - Posttest)}

Although the differences in the course are also indicated in the table comments through the pre-test applied without the training and the experimental set suitable for the STEM interdisciplinary education approach performed, the results obtained are compared with the dependent sample t-test and the results are shown in Table 4.

Table 4. Dependent sample t-test results applied according to experimental group pretest-posttest results

\begin{tabular}{|c|c|c|c|c|c|}
\hline \multirow{2}{*}{ Pre-Test } & $\bar{X}$ & $\mathrm{n}$ & $\mathrm{S}$ & $t$ & $\mathrm{p}$ \\
\hline & 4,33 & \multirow{2}{*}{18} & \multirow{2}{*}{1,52646} & \multirow{2}{*}{$-11,890$} & \multirow{2}{*}{,000 } \\
\hline Post-Test & 8,66 & & & & \\
\hline
\end{tabular}

Looking at the results in Table 4, a significant difference was found in favor of the posttests of the students in the experimental group $(\mathrm{p}<.005)$. At the end of the research, the academic success of the students participating in the STEM study has been statistically improved.

\section{Rough Evaluation Form Findings}

According to the data we obtained with the rough evaluation form during the study, it will not be possible to say that every student has high motivation. It was observed that Student 1, Student 2, Student 4 and Student 7 were more motivated than other students in the group and were more active and willing to participate in the experiments. In addition, it will be possible to say that Student 5, Student 9, Student 11 and Student 18 have mastered the subject and their motivation increased as the study progressed, and that they carried out a successful study. Student 8, Student 9 and Student 17 did not choose to interpret the results after the study. However, other students interpreted the results and discussed them with other students. In addition, studies were conducted with a collaborative approach in the group where STEM studies were conducted and it was seen that Student 1 and Student 7 guided other friends in the design and coding experiments. 


\section{Student Interview Form Findings}

As a result of the STEM study, according to the data we obtained with the student interview form, all students state that they find the study relevant to the acquisition and that they can use theoretical knowledge. In addition, the students state that they have experienced where they can use the knowledge gained with this study. All of the students participating in the study expressed their opinions about increasing the applications for STEM interdisciplinary education approach. Student 10, Student 12, Student 13, Student 14 and Student 15 students on the interview form: "Did you have difficulty doing the study?" "Did you need to get help from your friends during the study?" They answered that yes to the question and stated that they were able to complete the study by getting help from their friends. Student 3, Student 5, Student 10, Student 17, Student 16, while the student took a more active role in the design part of the study, they needed the guidance of their friends in the coding part, but they successfully performed the coding part as a result of the guidance. Again, according to the data we obtained from the student interview form, the reason why these students need guidance is seen as the combination of science and information technologies and software course.

\section{Discussion and Conclusions}

In this study, the contribution of STEM interdisciplinary education approach to academic achievement was tried to be measured. For this purpose, an activity was realized by considering the 7th grade science course "explains the main factors affecting growth and development in plants and animals". Looking at the results of the academic achievement test in this study, it is seen that there is a significant difference in the academic achievement of the students in the experimental group. It can be said that this situation is due to the positive effect of interpreting realistic data obtained both during coding and via sensors by students. In addition, it was observed that the study group students supported and provided peer learning and collaborative learning teaching methods by experiencing leaves (Özdemir, Aslay, Funda, Akar \& Baran, 2016; Koç \& Şimşek, 2016).

Yildirım and Altun (2015) state that they are effective in increasing the level of learning in a study they carried out with the STEM interdisciplinary education approach on the subject of science lessons. Similar results were obtained in this study, and it was observed that experimental group students had positive effects on their learning. Yıldırım and Selvi 
(2017) conducted a study on the STEM interdisciplinary education approach and the effects of full learning. In these studies, STEM practices and attitudes of full learning towards academic success, questioning learning skills, motivation, permanent learning and STEM practices were examined. It is seen that positive results about STEM applications have been achieved in similar studies (Kizllay et al., 2019). By stating that STEM applications have positive results as a result of the study, it supports the results we obtained from our study.

Students' "Where will we need this information?" in this study, which can answer the question, STEM interdisciplinary education approach was applied and students were provided with solutions to real world problems. The students have created a joint study using the information they have obtained from different disciplines and they have an idea about where the information they will use will be used (Sarı \& Kirınd1, 2019). Experimental group students were able to transfer the knowledge they learned in information technologies and software courses to different disciplines. Based on this, it is possible to say that students can have an idea about expanding their perspectives and interpreting their gains especially in mathematics and science course.

Based on the results we obtained in our study, the suggestions can be explained as follows. Within the scope of STEM interdisciplinary education approach, it was seen that arduino based experimental design designed for the acquisition of science lesson "explains the main factors affecting growth and development in plants and animals" positively beneficial to students' attitude and learning. Therefore, the study can be extended with units for different grade levels and different courses. In the in-service training given to teachers, the material designed in our study can be presented as an example. In the study, the data obtained from the sensors can be collected on a web-based platform and the plant's growth process can be observed by remote monitoring.

Units where STEM interdisciplinary education approach can be processed at all grade levels can be added. The content of different courses can be planned in parallel for the implementation of STEM studies. In order to ensure that prospective teachers can meet STEM studies early, courses related to this subject can be given in Education Faculties and in-service trainings can be given to teachers who teach in the profession. The content of assignments given to students can be arranged so that they can conduct STEM studies. 
Acknowledgment

This study has been produced from the master's thesis continuing by the first author under the supervision of the second author.

The data used in this study was confirmed by the researcher that it belongs to the years before 2020.

Authorship Contribution Statement

Faruk ÖZTÜRK: Literature review, conceptualization, methodology, document review, findings, hardware and software design

Durmuş ÖZDEMIR: Conceptualization, methodology, supervision writing-reviewEediting, interpretation, conclusion

\section{References}

Akçetin, E. (2017). Designing undergraduate curriculum for management information systems (MIS) education: a comparison of the mis programs of Turkish universities with those of global universities. Journal of Computer and Education Research, 5(9), 5060.

Akyüz, H. İ., Bilgici, G. \& Yıldız, İ. (2018). Investigation of the effects of robotic application and 3 dimensional design development activities on students' problem solving and creative thinking skills. 12. Uluslararası Bilgisayar ve Öğretim Teknolojileri Sempozyumu (Özet Bildiri Kitabı), 2-4 Mayıs, Özdere/İzmir. (s. 116)

Aydeniz, M., Cakmakcı, G., Cavas, B., Ozdemir, S., Akgunduz, D., Corlu, M. S., \& Oner, T. (2015). STEM eğitimi Türkiye raporu: Günün modası mı yoksa gereksinim mi? [A report on STEM education in Turkey: A provisional agenda or a necessity?] [White Paper]. İstanbul, Turkey: Aydın Üniversitesi. Retrieved May 31, 2015.

Bobtsov, A. A., Pyrkin, A. A., Kolyubin, S. A., Shavetov, S. V., Chepinskiy, S. A., Kapitanyuk, Y. A., \& Surov, M. O. (2011). Using of lego mindstorms nxt technology for teaching of basics of adaptive control theory. IFAC Proceedings Volumes, 44(1), 98189823.

Büyüköztürk, Ş., Kılıç Çakmak, E., Akgün, Ö. E., Karadeniz, Ş. \& Demirel, F., (2011). Bilimsel araştırma yöntemleri [Scientific research methods], (8th. Edition). Ankara: Pegem Pub.

Demirer, V. \& Nurcan, S. A. K. (2016). Dünyada ve türkiye'de programlama eğitimi ve yeni yaklaşımlar [Programming education and new approaches around the world and in Turkey]. Eğitimde Kuram ve Uygulama, 12(3), 521-546.

Docekal, T., \& Golembiovsky, M. (2018). Low cost laboratory plant for control system education. IFAC Papers OnLine, 51(6), 289-294.

Efe, H.A., Oral B., Efe R. \& Sünkür M.Ö (2011). The effects of teaching photosynthesis unit with computer simulation supported co-operative learning on retention and student attitude to biology]. Necatibey Eğitim Fakültesi Elektronik Fen ve Matematik Eğitimi Dergisi, 5(1), 313-329. 
Gök, M. (2020). Sınıf öğretmeni adaylarının bir mobil oyun deneyimi: aritmetiğin temel teoremi [A mobile game experience of pre-service elementary teachers: the fundamental theorem of arithmetic].Journal of Computer and Education Research, 8(15), 41-74.

Karahoca, D., Karahoca, A., \& Uzunboylu, H. (2011). Robotics teaching in primary school education by project based learning for supporting science and technology courses. Procedia Computer Science, 3, 1425-1431.

Kızıl, Ü., Aksu, S., \& Çamoğlu, G., (2018). Desing of an arduino compatible soil moisture monitoring system for plant production in a controlled environment. ÇOMÜ Ziraat Fakültesi Dergisi, 6(2), 131-139.

Koç, A. \& Böyük, U. (2013). Fen ve teknoloji eğitiminde teknoloji tabanlı öğrenme: Robotik uygulamaları [Technology based learning in science and technology education: robotic applications]. Journal of Turkish Science Education, 10(1), 139-155.

Koç, Y. \& Şimşek, Ü. (2016). İşbirlikli öğrenme yöntemlerinin 7. sınıf "maddenin yapısı ve özellikleri ünitesi" üzerine etkisi [The effectiveness of cooperative learning methods on 7th level "the structure of matter and properties" unit]. Journal of Computer and Education Research, 4(7), 1-23.

Kuo, H. C., Tseng, Y. C., \& Yang, Y. T. C. (2019). Promoting college student's learning motivation and creativity through a stem interdisciplinary pbl human-computer interaction system design and development course. Thinking Skills and Creativity, 31, $1-10$.

MoNE, (2015). 2015 STEM eğitim raporu [2015 STEM education report]. Millî Eğitim Bakanlığı, Yenilik ve Eğitim Teknolojileri Genel Müdürlüğü (YEĞİTEK). $<$ http://yegitek.meb.gov.tr/www/meb-yegitek-genel-mudurlugu-stem-fen-teknolojimuhendislik-matematik-egitim-raporu-hazirladi/icerik/719 >. (Erişim:04.11.2018).

MoNE. (2018). Fen bilimleri dersi (ilkokullar ve ortaokul 3, 4, 5, 6, 7 ve 8. sinuflar) öğretim program [Science courses curriculum (primary and secondary school 3, 4, 5, 6, 7 and 8 grades)]. Ankara: Talim ve Terbiye Kurulu Başkanlığı.

Özdemir, D., \& Karaman, S. (2017). Investigating interactions between students with mild mental retardation and humanoid robot in terms of feedback types. Education and Science, (42), 109-138.

Özdemir, D., Aslay, F., Akar, F., \& Baran, A. (2016). Sınıf yönetimi yazılımının işbirlikli yöntem ile programlama temelleri dersinde kullanımının öğrenci başarısına etkisi [The effect of use of classroom management software in programming fundamentals course with collaborative method on student success]. Journal of Computer and Education Research, 4(7), 47-64.

Qidwai, U., Riley, R., \& El-Sayed, S. (2013). Attracting students to the computing disciplines: A case study of a robotics contest. Procedia-Social and Behavioral Sciences, 102, 520-531.

Priyanka, S. S., Sangeetha, R., Suvedha, S., \& Vijayalakshmi, M. G. (2017). Android Controlled Fire Fighting Robot. International Journal of Innovative Science Engg. and Technology, 3.

Samsudin, M.A., Jamali, S.M., Zain, A.N.M., \& Ale Ebrahim, N. (2020). The effect of stem project based learning on self-efficacy among high school physics students. Journal of Turkish Science Education, 17 (1), 94-108.

Saraçoğlu, M., \& Kahyaoğlu, M. (2018). Ortaokul öğrencilerinin bilimsel sorgulama becerileri algılarının, merak, motivasyon ve tutum açısından incelenmesi [Examination of 
secondary school students' scientific inquiry skills perceptions in term of curiosity, motivation and attitude]. Journal of Computer and Education Research, 6(12), 358-376.

Sar1, U. \& Kırınd1, T. (2019). Using arduino in physics teaching: arduino-based physics experiment to study temperature dependence of electrical resistance. Journal of Computer and Education Research, 7(14), 698-710.

Sarıoglu, S. \& Girgin, S. (2020). The effect of using virtual reality in 6th grade science course the cell topic on students' academic achievements and attitudes towards the course. Journal of Turkish Science Education, 17 (1), 109-125.

Sayın, Z., \& Seferoğlu, S. S. (2016). Yeni bir 21. yüzyıl becerisi olarak kodlama eğitimi ve kodlamanın eğitim politikalarına etkisi. Akademik Bilişim Konferansı Bildiriler Kitabı 3$5,821-827$.

Tekkaya, C., \& Balc1, S. (2003). Öğrencilerin fotosentez ve bitkilerde solunum konularındaki kavram yanılgilarının saptanması [Determination of students' misconceptions concerning photosynthesis and respiration in plants]. Hacettepe Üniversitesi Eğitim Fakültesi Dergisi, 24, 101-107.

TIBA, (2015). 2023'e Doğru Türkiye'de STEM Gereksinimi. $<$ https://tusiad.org/tr/yayinlar/raporlar/item/9735-2023-e-dog-ru-tu-rkiye-de- stemgereksinimi>. (Erişim: 15.11.2018).

Xi, CTY, Daud, MZ, Muda, WMW \& Jusoh, MA (2017). LDR sensörü kullanarak mikrodenetleyici tabanlı güneş takip sisteminin geliştirilmesi. Telekomünikasyon, Elektronik ve Bilgisayar Mühendisliği Dergisi (JTEC), 9 (2-7), 71-75.

Yıldırım, B., \& Altun, Y. (2015). STEM eğitim ve mühendislik uygulamalarının fen bilgisi laboratuar dersindeki etkilerinin incelenmesi [Investigating the effect of stem education and engineering applications on science laboratory lectures]. El-Cezeri Journal of Science and Engineering, 2(2), 28-40. 